\title{
床暖房部品・構法の開発に関する研究 \\ A STUDY ON DEVELOPMENTS OF BUILDING SYSTEMS AND BUILDING PARTS FOR FLOOR HEATING SYSTEMS
}

\author{
大島隆一*, 小西敏 正**, 桝田佳寛** \\ Ryuichi OSHIMA, Toshimasa KONISHI and Yoshihiro MASUDA
}

\begin{abstract}
Building parts and building systems are changed with the times. But records of development and changes of details are not almost handed down. Those records of change will be helpful to produce better development. In this study, we took notice floor heating systems, and surveyed connection between researches on patent and literature about those changes. As a result, the floor heating systems have importance to the improvement in floor of building parts, panels and dry building systems, and requirements of related to the manufacture/construction and the heat.
\end{abstract}

Keywords: Floor Heating Systems, Patents, Building Systems, Building Parts, Development 床暖房, 特許, 構法, 建築部品, 開発

\section{1.はじめに}

建築部品や建築構法の新たな開発は，建築技術の発展を促す大き な要因と言える。そのため, 建築部品・構法開発の詳細な経緯を把 握することはきわめて重要である。しかし近年, 製品化された建築 部品や標準化された建築構法は多種多様で，それらを支える技術も 多岐にわたり, 分類整理されていないのが現状である。また, 製品 化された部品や一般化して, 標準化された構法であっても, 開発段 階の詳細な記録やディテールの変化は, 整理されておらず, 殆どの 場合, その変遷は明確にされにくい。多種多様に存在する建築部品 や建築構法の個々の事象について，その開発のプロセスや発見・発 明の内容を明確にし, 後世に伝達することは, 次の改良・発展に対 して, 有意義だと考えられる。既存の研究内容が明確に整理されて いれば，要求性能の水準が更に高められ，合理的な発展が容易にな ると考えられる。そのため, 建築部品・構法に対する要求された性 能や開発内容を詳細に調査する方法を見いだし，その方法を使って 建築技術の発展を知ることを本研究の目的とした。

ところで, 建築構法と深く関連し, 他の建築部品と合わせて機能 を発揮するものの代表として床暖房がある。本研究ではその構法, 材料・部品等の開発経緯やその動機となった要求性能等を調查分類 し, 我が国の一般的な床暖房に対する需要や技術的側面, 特許の申
請内容がどのような変化を示しているかを明らかにする。

\section{2. 調查概要}

本研究は，床暖房に対して技術的な開発の詳細や要求を整理し， 床暖房開発の要因と変化を把握することを目的とする。そのために, 研究対象として文献調查を行い, 床暖房に関する一般文献と特許情 報註1)を利用した。

一般に新技術に対する研究・開発の結果は, 特許情報に示される ところが多い。建築分野における, 構・工法開発や新材料・部品の 開発, 研究においても, 特許制度が活用される。特許における開発 の研究内容には一般的に普及されなかったものも含まれており, そ の中に重要な要因が含まれている場合も少なくない。従って，床暖 房に対して, 一般文献ではあらわれない技術開発の詳細な内容や要 求性能の把握及び総括的な技術要因の分類整理を, 特許情報を利用 して調査した。

本研究の調査方法は, まず一般文献により, 概括的な発展過程を 把握する。次に, 特許により床暖房について開発された技術を分類 整理し, 年次変化を分析して一般文献による床暖房の発展を示す事 象と関連づけて検証し，その変化の要因について考察を行う。その 際, 特許による調査は 1970 年以降を対象とした。その理由として

本研究は，参考文献10)，11）において発表したものをもとに，加筆・修正を加えたものである。

* 宇都宮大学大学院工学研究科博士後期課程

生産・情報工学専攻 大学院生・工修

Graduate Student, Production and Information Science Eng., Docter's Degree,

** 宇都宮大学工学部建設学科 教授·工博

Prof., Dept. of Architecture and Civil Eng., Faculty of Eng., Utsunomiya Univ., Dr. Eng. 
表- 1 一般文献の調査のための項目

\begin{tabular}{|c|}
\hline 開発年代 \\
\hline 場所・人・企業 \\
\hline 開発床暖房の種類 (熱源) \\
\hline 使用材料・構法 \\
\hline 要求性能事項 \\
\hline 次開発への要因 \\
\hline
\end{tabular}

1970 年以前は，床暖房に関する工業会が発足されてなく，床暖房 の開発研究を早期から行っていた企業等は数社に限られ，その企業 が考案した特許事項に該当すると考えられる床暖房の開発研究の要 因とその変化については，一般文献による調查で十分収集できるか らである。しかし，1970 年代に工業会が発足した後は，技術の高 度化や多様化が促進され，一般文献の調査では，商品化されない開 発研究の詳細事項や要求性能の変化等が把握できなくなっている。 従って，1970 年以降は，一般文献による暖房の発展に関する事 象を，特許調査の結果により検証することとした。

\section{3. 一般文献の調查}

\section{3-1 対象とした一般文献}

一般文献の調查では，本研究に関連した設備や環境関連の書籍， 構法関連の記事等の収集の他, 関連部品・構法に携わる建築団体へ の資料や情報の請求等の情報収集住2) を行い，対象部品・構法の開 発等の情報の所在を明確化し、デー夕整理を行った。これらの整理 結果から，床暖房に関する需要等を抽出した。また，書籍や構法関 連記事等の文献中に述べられている㦿暖房の発展に関する事象に注 目して，1930 年代から抽出した。これを総括して变遷概要とし， また，その結果を特許の調查と比較検討した。

\section{3-2 一般文献調査の結果}

床暖房に関する一般文献による, 需要 ${ }^{1)}$ と装置における寸法,

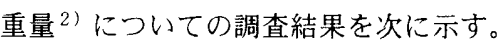

(1) 床暖房の需要について

床暖房の需要は，図一 $1^{11}$ のように 1970 年代から近年にかけて， 温水式，電気式とも増加傾向にある。ここで言う床暖房はそれに関
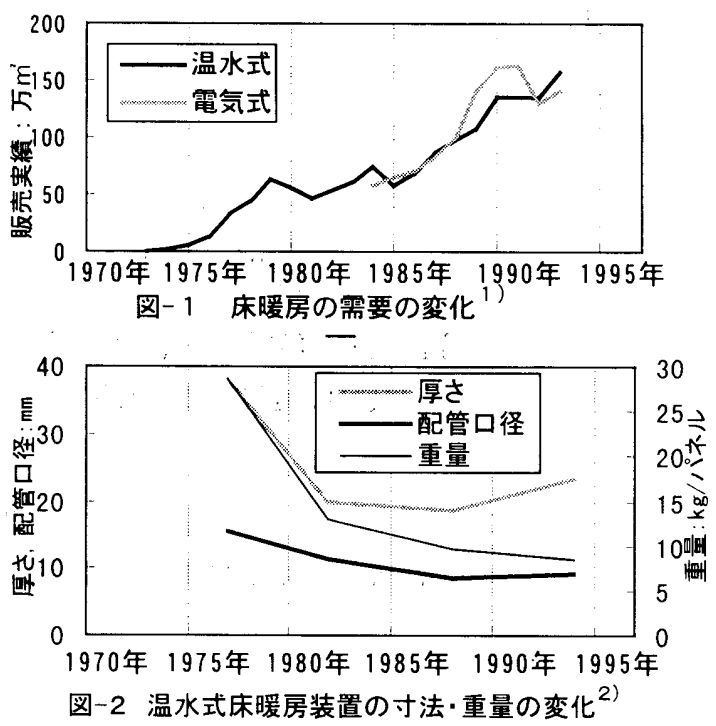

する工業会に属した会員企業によるもので，そこで販売していた住 宅用, “住宅以外の対人施設，非対人施設関係床暖房全ての装置の実 績数である。

(2) 温水式床暖房装置の寸法・重量について

図- $2^{2)}$ の温水式床暖房装置の寸法について，その厚さは，全 体的にやや薄型化の傾向が見られるが，最近は，薄型化の傾向は見 られていない。また，配管口径は若干ではあるが小さくなる傾向に あり, 重量は軽くなっている。

(3) 林暖房の変選概要について

書籍や構法関連記事等の文献 ${ }^{3)}$ の中で述べられている床暖房の 発展に関する事象については, 熱源や設置構法, 要求性能等を重要 と考え, 表一1のような休暖房の種類・熱源, 使用材料・構法, 要 求された事項等の項目作成を行い集計した。その結果，図一 3 のよ うな, 温水式と電気式床暖房別の変遷概要 ${ }^{3)}$ のフローを作成した。 その内容は以下のようになる。

1931 年に日本で初めて登場した㦿暖房は, 湿式工法・温水式で

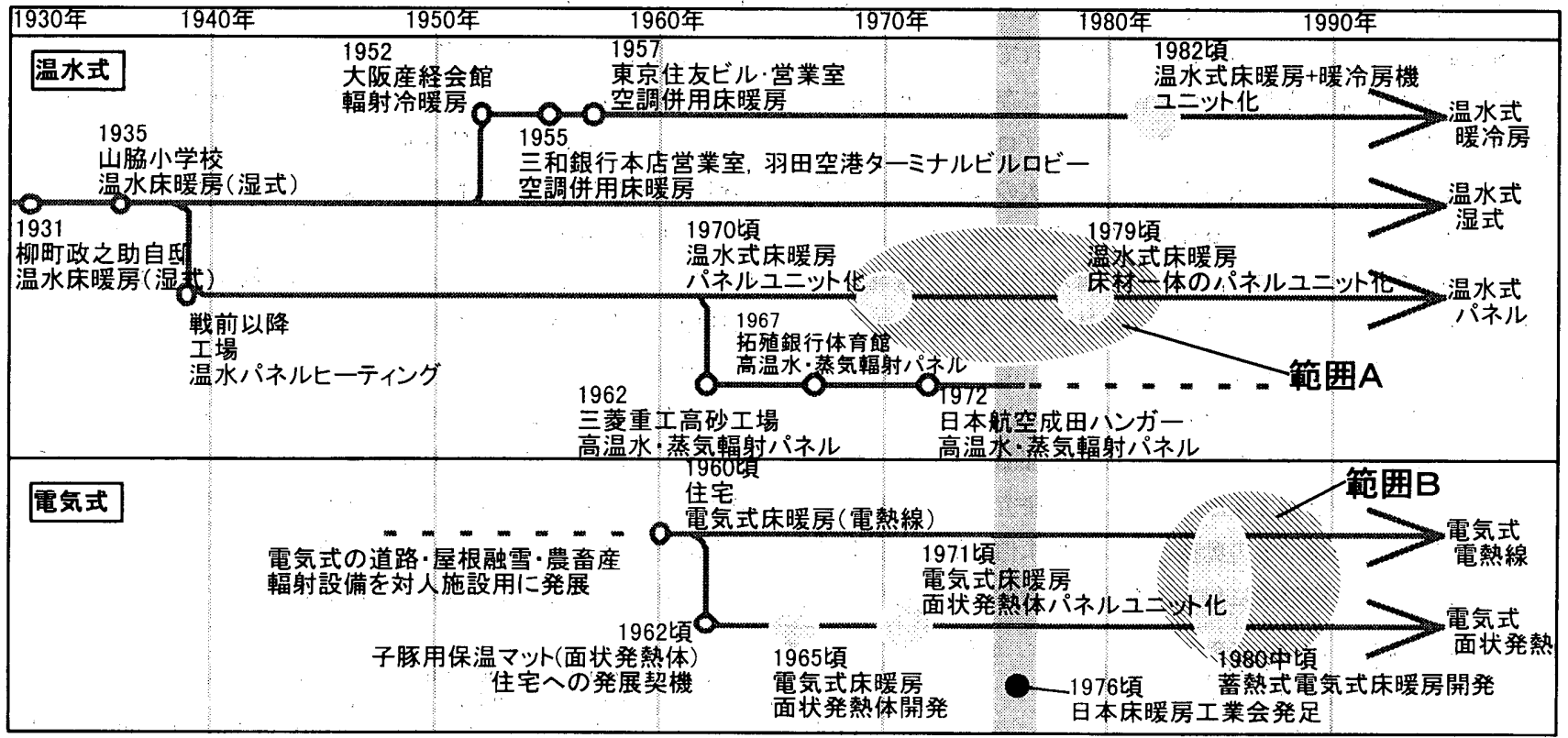

図-3 床暖房の変遷概要 ${ }^{3}$ 
あった。戦前, 軍需目的の工場に有効な暖房が必要となり，休暖房 が利用された。1962 年以降, 工場での床暖房に天井や側壁からの 高温水パネル暖房が考えられ, 現在のパネルユニット化の先駆けと なっている。パネルユニット化された温水式の床暖房は, 1970 年 頃からはじまり, その後 1979 年頃に床材一体ユニットの商品も出 現した（図ー 3 中範囲A）。

電気式床暖房では, 道路や屋根融雪, 農畜産等に利用していた設 備を改良し，対人施設に応用したのが 1960 年頃からである。初期 は電熱線埋込であったが，大面積で熱を得ることが要求され，1965 年頃, 子䀠用保温マットを住宅向けに改良した面状発熱体の開発が 行われた。その後 1970 年代に, 面状発熱体の電気式パネルユニッ トが住宅用として出現した。また, 料金の安い深夜電力利用による 蓄熱式電気床暖房が 1980 年中頃に開発された(図一 3 中範囲 B)。

\section{3-3 まとめと課題}

図ー3に示した床暖房自体の変遷において, 本研究では, 対象を 限定したため全てを網羅したわけではないが, 重要な開発事象につ いては提示できたと考えられる。

一般文献の調查により, 床暖房はその需要から見ても発展し続け ている状態にあることが概括的に把握できた。しかし，床暖房装置 の寸法や重量については，近年変化が見られず，また，温水式床暖 房のパネルユニット化や床材一体パネルユニット, 電気式の蓄熱式 床暖房については, 要求性能や開発内容が明確でなく, その変化の 詳細は定かでない。これらを全体的な技術内容から調查するために は，ある企業に限った事実ではなく，全体的に見た特許の内容から 調査し, その要因を把握して変化の特徽を判断する必要があると考 えられる。このことから, それらの発展的な事象について特許によ り検証する。

\section{4. 特許・実用新案に見る床暖房の開発動向}

\section{4-1 対象とした特許・実用新案}

特許・実用新案の調査は，まず，その膨大な特許数から床暖房に 関する特許の抽出を行うため, 予備調查を行った。

予備調査は床暖房に関する特許・実用新案の所在を検索するため, 近年の公開特許 ${ }^{4)}$ を利用し，どの分類範囲を調査すべきかを検討し た。その際，林暖房に対する一般的なキーワードである「床暖房， ヒーティング, 輻射, 面状発熱体」等の用語を手がかりに調查を行 った注3)。

この結果, 林暖房に関する特許・実用新案は, 8 分類中の建築の

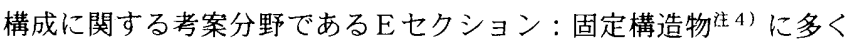
収録されていた。更に電気や機械工学, 加熱等の特許分野にも収録 されていた。また, 複数の分野にまたがって収録されているものも あった。本研究では，床暖房における部品や設備単体の特許よりむ しろ，建築部品・建築構法への関連性を重要視しするため, E七ク ション: 固定構造物の分野について研究対象とした。従って, 電気 や機械工学, 加熱等の特許分野に限って入る暖房関連特許は研究 対象外とし, $\mathrm{E}$ セクション: 固定構造物の分野に入っていて，その 他の分野にも入っている特許は，本研究の対象とした。

本検索はその分類範囲と「床暖**」をキーワードとして，コンピ ユーター検索社5)を行い，それらを資料としてデー夕化を行った。 対象とした特許のデー夕範囲は 1972 年から 1996 年までで, 特許 271

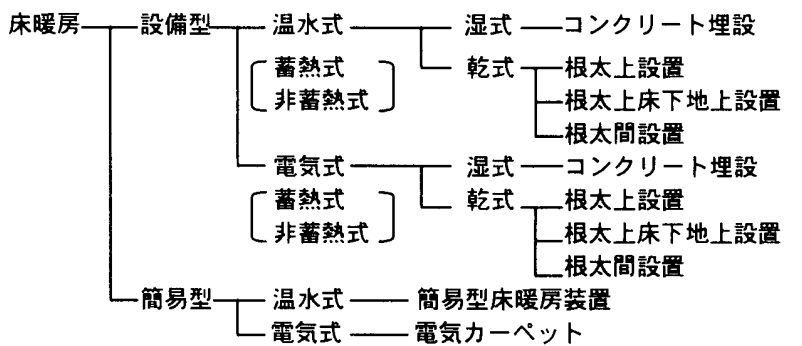

図-4 床暖房の熱源・構法別種類 ${ }^{5}$

表-2 特許による熱源・設置構法別の分類

\begin{tabular}{|c|c|c|}
\hline & 熱源別 & 設置搆法別 \\
\hline 击 & 温水式 & 乾式 \\
\hline 要 & 電気式 & 湿式 \\
\hline 類 & 温水·電気両方式” & 乾·湿式両方式 $\cdots)$ \\
\hline 筫 & その他の熱源“的 & その他の構法….) \\
\hline
\end{tabular}

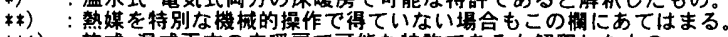

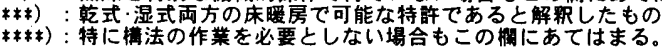

表-3 特許による要求性能事項・開発研究事項別の分類

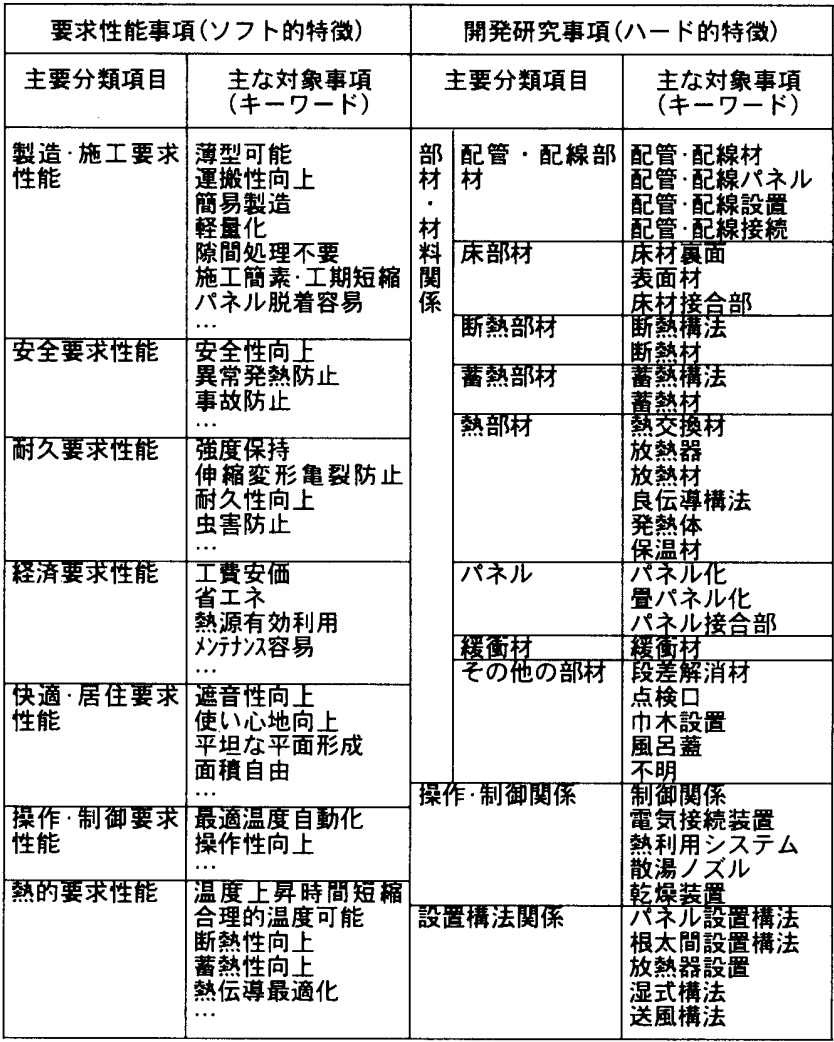

件，嵩用新案 275 件となり，収集した特許・訔用新案の資料は，1 件毎に要約と図が記載されている。

\section{4-2 特許・実用新案資料の解析方法}

得られた特許・実用新案のデー夕を床暖房に関する技術体系の整 理として明確にするため, まず，木暖房においてその熱源と設置構 法を重要視し, 現状の製品の種類を把握して, 文献 ${ }^{5)}$ により図一 4 のような分類を行った。この分類の内容は，まず，床暖房を設備 型之簡易型に分けている。本研究では，簡易型は建築構法と関連性 が小さいため研究対象外とした。本研究対象の設備型では熱源が温 
水, 電気に区別され, その各々に乾式, 湿式工法が存在する。各工 法は湿式でコンクリート埋設型, 乾式で根太上・根太上床下地上・ 根太間設置構法として区別される。この乾式・湿式の技術内容は各々 の熱源について同様であり, また, 各々の熱源に蓄熱式・非蓄熱式 の技術が存在する。

この分類方法を特許における床暖房関連の考案に当てはめ, 熱源 及び設置構法別に分類した（表一2）。ここで, 熱源の区別がつか ない特許は，その要約文の内容からどちらの熱源でも可能な特許で あるとし，温水・電気両方式の項目を作成し区別した。設置構法に おいても同様であり, 乾・湿式両方式の項目とし区別した。また, 温風を床下送風で床暖房を行う場合や蒸気を熱媒とした場合等は, その他の熱源として区別し, 浴室床に温水を散湯する等の設置構法 は，その他の構法とした。

次に，收集したデー夕の要約文から１件毎に，特許出願年月日， 発明名称, 出願人, 特許のソフト的特徵, ハード的特徵の項目分け を行い，年代毎に集計した。このソフト的特徵を要求性能事項 ${ }^{6)}$, ハード的特徵を開発研究事項とし, それぞれの主な対象事項として のキーワードを抽出し, 主要分類項目として整理した（表ー3）。

ここで, 要求性能事項や開発研究事項が特許 1 件中に複数個存在 した場合, その出願当時の要求や開発が複数必要だった事実を重要 視し， 1 件毎の考案数として数えた。従って, 収集した特許の件数 より要求性能事項数や開発研究事項数の合計の方が多くなった。表 中の主な対象事項（キーワード）数は, 要求性能事項が 120 件, 開 発研究事項が 36 件となった。また, 要求性能事項はキーワード数 が多くなったため, 類似な要求に対し，グループ化を行った。例え ば，「床段差の解消」や「床高さを一定」等の要求に対しては「平 坦な平面形成」と言う項目にした。要求性能事項のキーワード数 120 件が, グループ化した後の件数である。

以上の集計による特許資料を, 上述の熱源及び設置構法別分類と, 要求性能事項, 開発研究事項別に再度年代毎の集計を行った。開発 研究事項の主要分類項目は, 部材・材料関係と操作 ·制御関倸, 設

\begin{tabular}{|c|c|c|c|c|c|}
\hline 設置構法別 & 温水式 & 電気式 & $\begin{array}{c}\text { 温水・電気 } \\
\text { 方に閶す } \\
\text { る特許 }\end{array}$ & $\begin{array}{l}\text { その他 } \\
\text { の熱源 }\end{array}$ & $\begin{array}{l}\text { 不 } \\
\text { 明 }\end{array}$ \\
\hline 乾式 & \multirow{5}{*}{\multicolumn{5}{|c|}{$\begin{array}{c}\text { 熱源別と設置構法別の該当橌に } \\
\text { 出願特許番号や出願年月, } \\
\text { 分類して表記。記。 } \\
\text { 件数の分布によりその重要性が示される。 }\end{array}$}} \\
\hline 湿式 & & & & & \\
\hline $\begin{array}{c}\text { 乾式・湿式両方 } \\
\text { に関する特許 }\end{array}$ & & & & & \\
\hline その他の拉法 & & & & & \\
\hline 不明 & & & & & \\
\hline
\end{tabular}

表- 5 開発研究事項一要求性能事項別の分布表

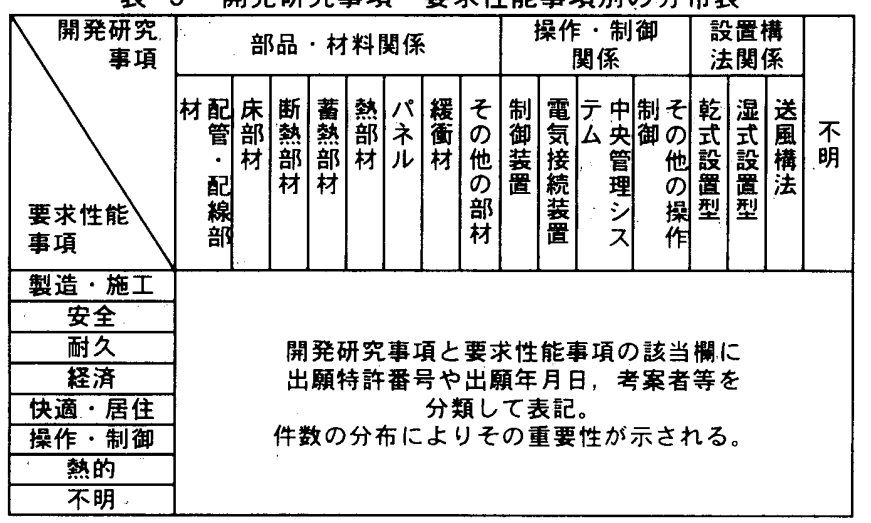

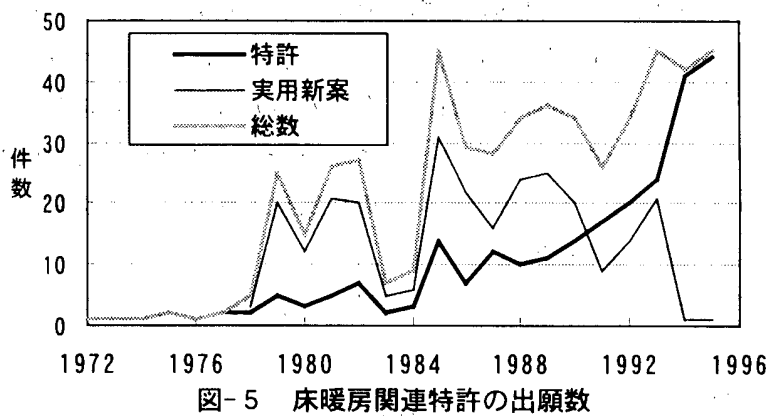

置構法関係に大別でき, 要求性能事項は製造・施工, 安全, 耐久, 経済, 快適・居住, 操作・制御, 熱的要求性能の 7 つが重要な分類 となった。これらの主要分類項目毎の年次変化声 6) を調べ考察し, また, 一般穴献による床暖房の発展に関する事象の調査結果と比較 し検証した。

\section{$4-3$ 特許・実用新案の調査結果}

図ー 5 に床暖房に関する特許・実用新案の出願数を年次変化とし て示す。この結果, 特許においてはその出願数が増加傾向にあり, 図-1の床暖房の需要の変化傾向と一致している。近年において床 暖房は発展していることが特許においても分かる。

実用新案の分布は増減を繰り返している。寒用新案は物品の形状, 構造又は組合せにかかるもので，理論の考案ではない。従って，実 用新案は新規の特許に対して多くのハード面を考案し出願が増える ことがあるため, 今回のような增堿が激しい結果を示すことがある。 近年の実用新案の低下は，特許の出願数が多いことから，床暖房に ついて理論や方法を考えることに重点がおかれ，物品に対する創作 の出願は殁どなされていないことが分かる。

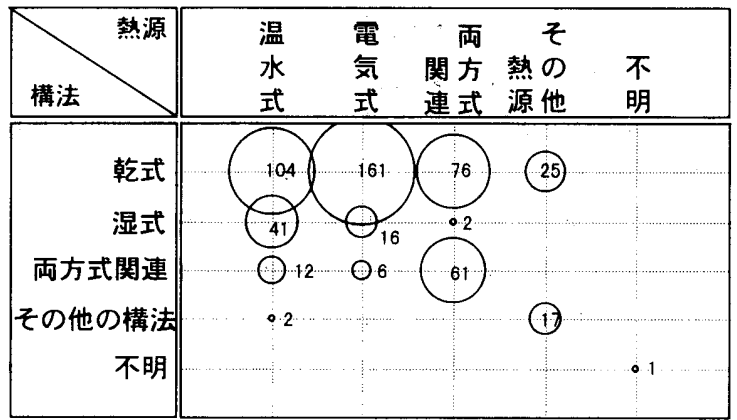

図-6 熱源-設置構法の分布数（1972～1996年）

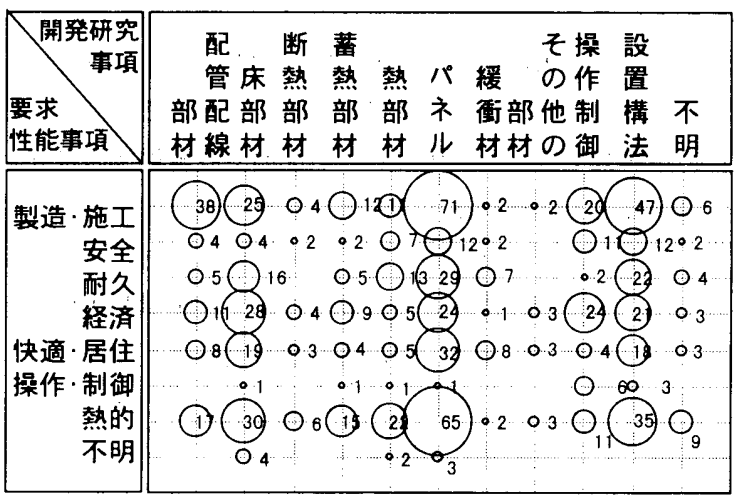

図-7 開発研究事項-要求性能事項の分布数 (1972 1996年) 


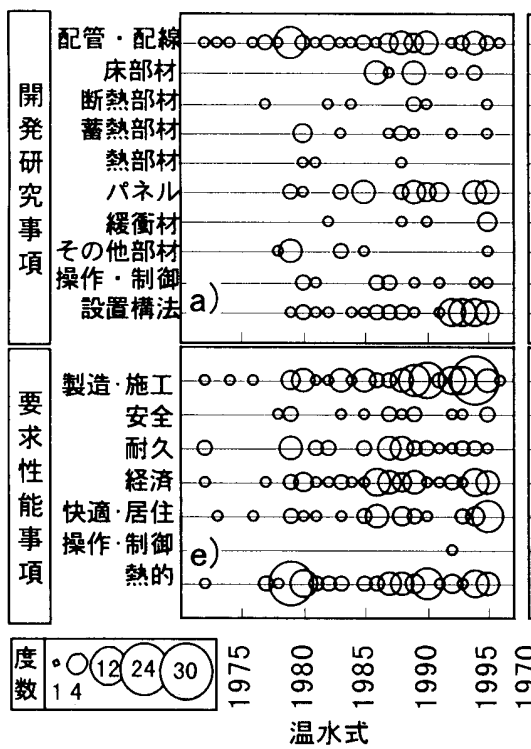
温水式
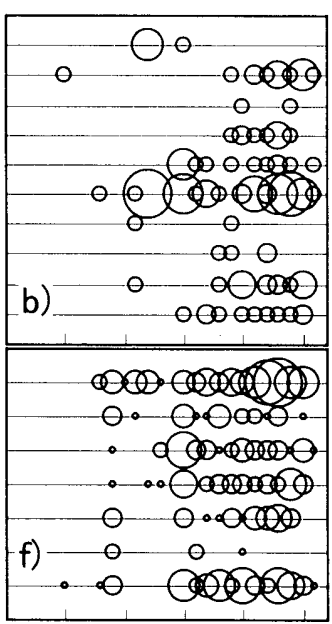

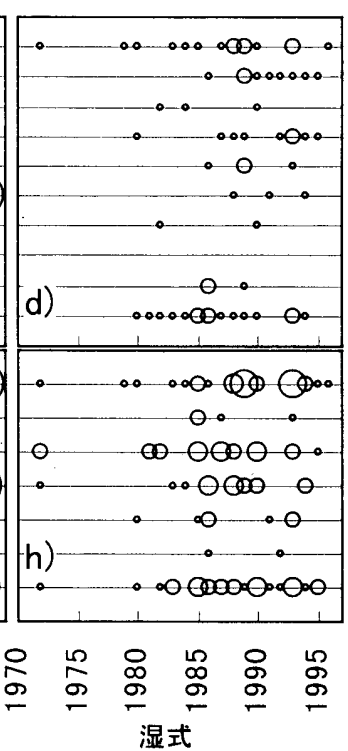

図-8 開発研究事項·要求性能事項と熱源·設置構法の特許出願年次変化

(1) 床暖房に関する技術の特許の整理

以上のように，床暖房に対する技術的な特許の分類が明確化され た。次に，表 $-2 ， 3$ による各主要分類項目を用いて，表 $-4 ， 5$ のようなく熱源一設置構法>及び／開発研究事項－要求性能事項〉 別の分布表を作成した。これにより，既往開発研究の調査が容易に なり特許出願の重複を避けることが可能となる。また，㦿暖房に重 要な要因が明確に把握することができる。

調查結果として設備型休暖房の重要な技術要因は，図一 $6<$ 熱源 一設置構法>別に関して, 㦿暖房の基本的な構法である湿式工法・ 温水式の研究開発が, 乾式工法・電気式に比べて少ないことが分か る。本研究範囲では, 電気式に対して乾式の施工法が多くの考案で あり,その重要度を示す結果となった。

図一 7 <開発研究事項一要求性能事項>別では, 床部材やパネル, 設置構法に関する開発研究事項が多く，それらはほほ全ての要求性 能に対して開発研究を行っている。開発研究事項の設置構法が広い 分布を示していることは, 設備型の床暖房の開発研究が設備単体で 行われているのではなく, 建築構法と密接な関連で行われていると 考えられる。また, 要求性能事項に対しての開発研究事項は, 項目 毎に比較的ばらつきがあることが分かる。特定な要求性能に集中し た分布が見られないことは, 各要求性能を全体的に満たすように開 発研究が行われていることになる。

\section{4-4 考察}

(1) 特許・実用新案に見る要求性能・開発研究事項について

図一 8 中 a) に温水式の開発研究事項の年次变化を示す。図の円 の位置が特許出願時期で大きさがその分野の度数をあらわす。この 図によると配管部材に関する考案は調查対象年代の 1970 年代から 継続して特許がでている。またその数も多いことを特徵とし，確立 した技術がまだ存在しない分野で, 開発研究の価值が十分に残され ていると考えられる。その他の開発研究事項は，1980 年代からは じまっている。最近ではその設置構法の開発研究が盛んであること が分かる。

図-8中 b)の電気式では, 全体的に 1980 年代から開発研究がな されており,パネルの開発研究が多い。配線の開発研究は 1980 年

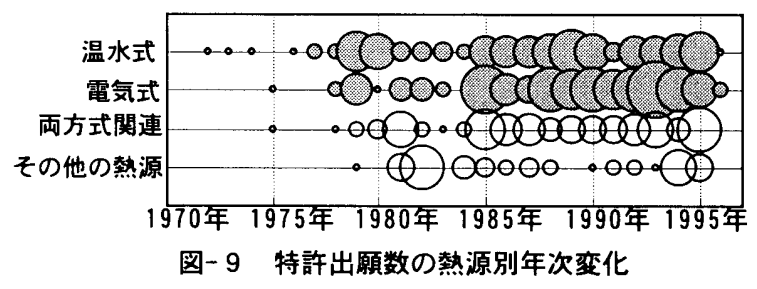

代前半にあるが，それ以降に考案がないのは面状発熱体の商品化の 影響であると考えられる。

図－8中 c)の乾式工法における開発研究事項の年次変化は, 分 布数が最も多いパネルに関しては継続した開発研究が行われており， その技術の豊富さがうかがえる。配管・配線による開発研究事項は, 1970 年頃から継続して開発研究されている。これは乾式工法にお いてもその配管・配線に関する研究開発がまだ確立した技術をもつ ていない分野であることを示している。

図-8中 d) の湿式工法に対する開発研究事項の年次変化は, 乾 式におされる形でその数は少ない。床暖房の技術は考案として種類 が豊富な乾式が定着しつつあるのが現状である。

要求性能事項について年次変化を考察すると, 図一 8 中 e) の温 水式に対する要求性能事項において，1970 年代末は, 熱的要求に 関するものが多かったが，1980 年以降は，製造・施工に関するも のが增加している。一方, 図-8中 f)の電気式では, 1980 年以降 に各要求が多く出現し，熱的要求，製造・施工要求とも，ほほ同時 に出てきており,近年においては温水式よりも多く要求されている。

図-8中 g)の乾式工法における要求性能事項の年次変化は, 全 要求性能に対してほぼ増加傾向にあり，その数も多いことから技術 開発への要求が豊富であることを示している。また, 乾式工法の製 造・施工と熱的要求が多いことが湿式への各要求の少なさに影響し ていると考えられる。

(2) 床暖房の需要と特許について

床暖房の需要は図 -1 より温水式・電気式共, 増加傾向にあるが, その詳細を特許により検証すると, 図一 9 の特許出願数の熱源別年 次変化で 1985 年頃は温水式よりも電気式に多くの考案があり，そ 


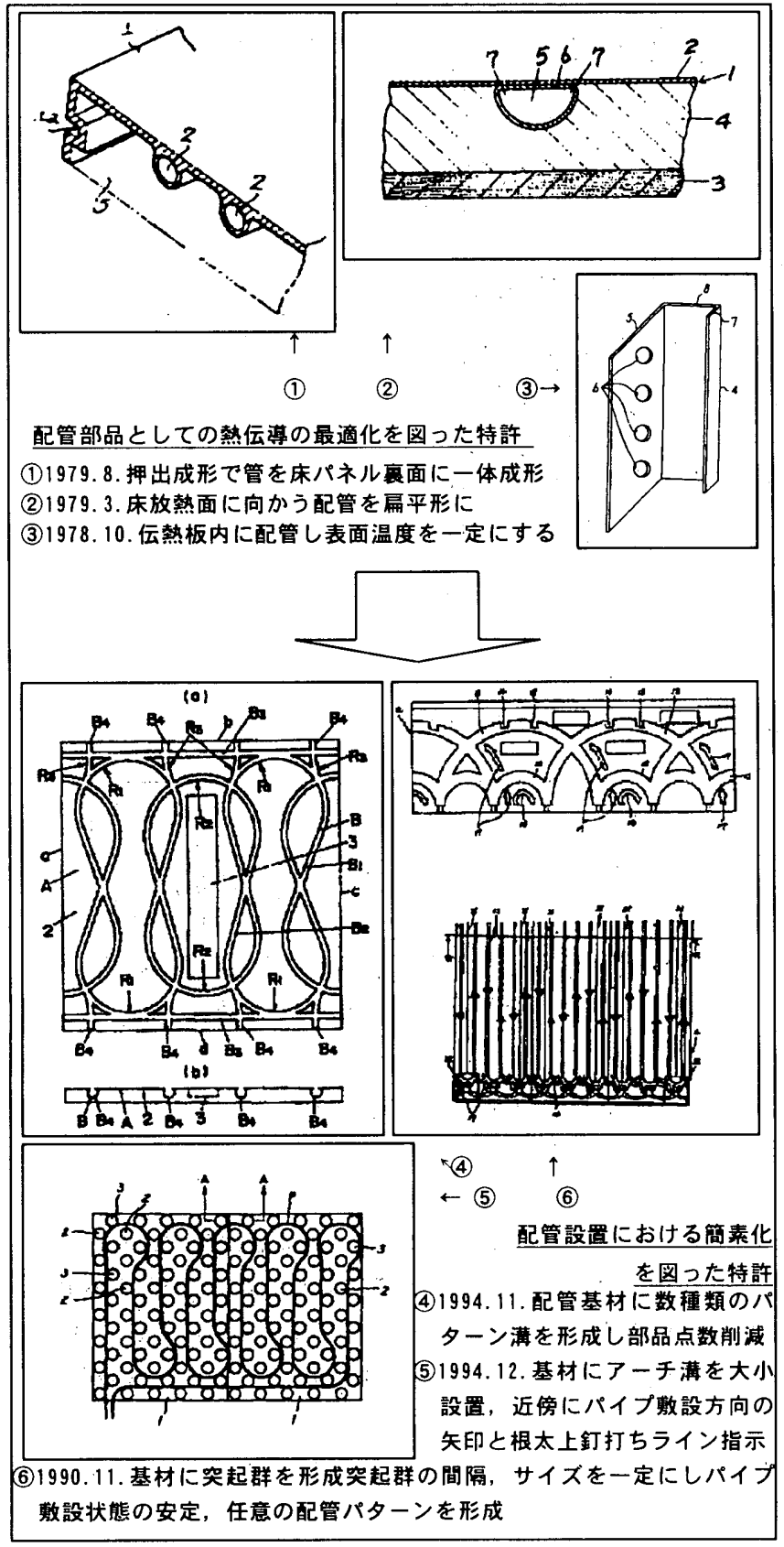

図一-10 温水式床暖房における配管関連特許の事例

の後 2,3 年間は温水式とほぼ同等数の特許がでている。これは温 水式・電気式相互の需要の傾向と一致している。1988 年頃から 1993 年頃までは電気式の需要が大きく，特許出願数も電気式が多い。こ のように, 床暖房装置の需要と特許には時期的に同じような分布変 化を示す傾向が見られた。

(3) 床暖房装置の寸法, 重量と特許について

図一 2 温水式休暖房装置の寸法について, 配管口径は若干, 小さ くなる傾向にあるが, 近年の薄型化の傾向においては顕著でない。 図一8中 a)における温水式による配管・配線部材開発研究の年次 変化は, 継続して開発研究が行われており, 配管口径を小さくする こともこの開発研究事項に含まれる。このことについて具体例を見 ると, 図ー10 のような配管関連の特許は, 配管口径を小さくした ことや薄型化にしたことによって生じる熱伝導の不適正をなくすた
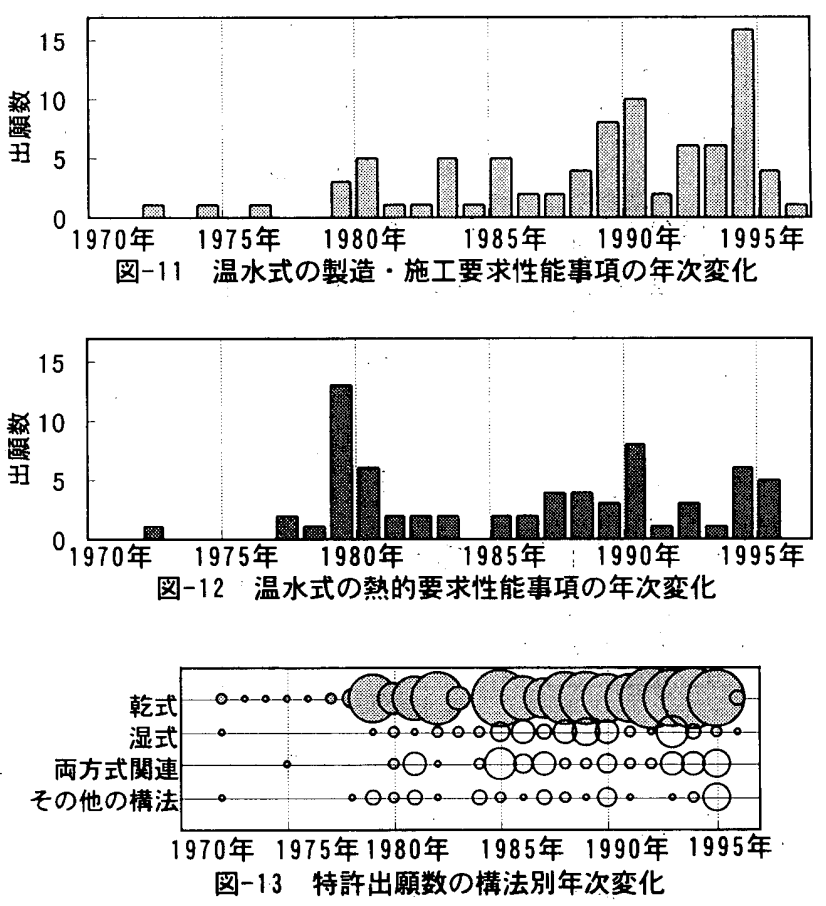

め，まず配管からの熱伝導を最適にするための部品を開発したこと でその要求を満たした。しかしその後, 施工性への配慮のため配管 設置の簡素化を目的とした要求が加わり，建材の構成（構法）でそ れを満たす方向へと移行した。この構法によって床暖房の薄型化に は物量的に限界が生じたと考えられる。これらのことから，薄型化， 配管口径の最小化を目的とする場合は，「配管部品で熱伝導に対し ての解決」，「建材の構成（構法）による配管設置の簡素化」のよう に, 開発の目的が重複するため, 様々な要求を解決しなければ完成 されない分野であると考えられる。

図一 2 による僈房装置の重量は軽くなる傾向にある。薄型化や 重量低減は，主に施工性に影響するため特許で検証すると，図一11 による温水式の製造・施工要求性能事項の年次変化は，年々增加す る要求となっている。また, 図一12 の温水式の熱的要求性能でみ ると、はじめは多いがやがて少なくなり，また增えている。これら の要求性能事項からみても，この温水式床暖房装置の開発は，第一 に熱に対しての開発が重要とされ，その開発がある程度の満足度で 得られた場合, 次に施工性への配慮が加わる形となっている。しか し，それに伴う熱的性能への要求は依然のこり，施工性への要求も 完全ではない状態となっている。つまり，温水式床暖房装置の薄型 化, 重量低減は，進行中の開発研究分野であり，その製造・施工要 求や熱的要求はこれからも要求される分野であることが分かる。

(4) 一般文献調査の変遷概要と特許について

変遷概要の図 -3 中範囲 Aについて, 1970 年頃からはじまった 温水式パネルユニットの床暖房と, 1979 年頃の床材一体ユニット の出現は, 温水式床暖房の中で原理的な開発として大きな特徵とな っている。これらを特許調查結果により検証する。

まず，図一 9 の特許出願数の熱源別年次変化の温水式, 及び, 図 -13 特許出願数の構法別年次変化の乾式工法は，1970 年代末から 考案が急增しており, 文献による温水式パネルユニットの開発事象 より後に考案が多い。しかし, それ以前の 1970 年代にもいくつか 


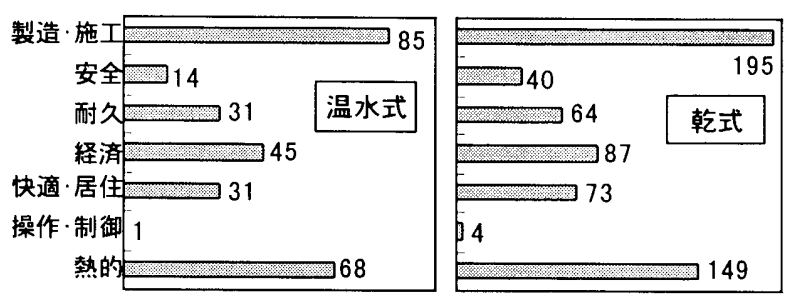

図-14 温水式及び乾式の要求性能事項分布数 （1972１996年）

の考案はある。また, 図ー8中 a)における温水式の開発研究事項 の年次変化で, パネルは 1970 年代末, 床部材は 1985 年以降に考案 があり, 画開発研究共, 文献で述べられた時期より後に考案が急增 している。これらのことから, 温水式パネルユニットや床材一体ユ ニットは, 原理的に出現してから技術的な発展の価值を見いだし，

試行錯誤し, 建築構法にも有効に働くよう考案して時期をずらして 多くの考案が急增したと考えられる。

温水式のパネルユニットや床材一体ユニットの出現による要求性 能は, 図-14 温水式及び乾式の要求性能事項分布数に見られるよ うに, 製造・施工要求と熱的要求に関するものが多い。ユニット化 は製造・施工性から要求され, 更に熱的な要求として総合的に最適 な熱分布を得ること等を可能にさせたことが, 発展を促し多くの技 術を生み出したと考えられる。

次に電気式床暖房について示す。変遷概要の図ー3中範囲 Bにお ける蓄熱式電気床暖房の開発事象（1980 年中頃）について特許よ り検証すると, 図一 8 中 b) の電気式の開発研究事項の年次変化か ら, 蓄熱部材が 1980 年代末以降の考案になっている。これは, 蓄 熱に良い部材を電気式床暖房に活用した 1980 年代中頃から, 開発 の価值や技術の多様さの結果, 蓄熱部材を含んだ構法の考案が, 特 許として 1980 年代末に出現したと考えられる。図一8中f)の電気 式の要求性能事項の年次変化では熱的要求が 1985 年頃から多くで ている。これに起因する電気式の熱部材に関する開発も, 図一 8 中 b)より 1985 年頃から盛んであり一致する。熱部材はその放熱や熱 伝導の最適化, 保温効果を得る等の熱に対する建築構法の開発であ ることから, 蓄熱にも考案として影響を与える。つまり, 熱的要求 による建築構法の考案が主体となり1985 年頃から行われ，1980 年 代末には蓄熱式電気床暖房が本格化したと解釈できる。

これらのように, 温水式の変化の特徵は, 床部材, パネルの開発 と製造・施工, 熱的要求にあり, 電気式は, 蓄熱部材, 熱部材, 熱 的要求性能事項から, 電気床暖房の開発研究に変化の特徵がある。 これらは，出願された特許によっても裏付けられた。

\section{5. まとめ}

床暖房に関する建築部品や建築構法の現在までの変遷を知り, 今 後の発展の合理化を促すため, 特許の内容により床暖房の技術要因 を熱源, 設置構法, 要求性能事項, 開発研究事項別に整理し, 一般 文献にあらわれる特徵とする変化と検証した結果, 以下のことが明 らかになった。

（1）設備型の㦿暖房の技術要因を整理することで, 床部材及びパネ ル, 設置構法開発研究が重要な要因として抽出できた。また, 電気 式では乾式の施工方法が技術として重要視されている。
(2) 温水式の開発研究事項では, 配管部材に関する開発が長年にわ たって行われてきたが，まだ技術として確立されておらず，また， 開発研究の余地が十分に残されている分野となっている。

(3) 電気式の開発研究事項は,パネルに関する開発が主であり,1980 年以降に多い。

（4）温水式に対する要求性能事項は, 1970 年代末は, 熱的要求に 関するものが多かったが，1980 年以降は，製造・施工の合理化に 関するものが増加している。一方, 電気式では, 1980 年以降に各 要求が多く出現し, 熱的要求, 製造・施工要求とも, ほぼ同時に出 てきており, 近年においては温水式よりも多く要求されている。 (5)特許において乾式工法と湿式工法を比べると, 1970 年以降, 殆どが乾式工法である。これは，(4)に関連し，製造・施工要求が 影響していると考えられる。

(6) 温水式, 電気式床暖房の需要の伸び乞特許出願数の増加は, 時 期的にほぼ同傾向を示す。

（7）温水式床暖房装置は，一般文献では薄型化の傾向が顕著でなく なってきているが，これを 1970 年以降の特許の内容から見ると,

配管部品の熱伝導の最適化の工夫や, 配管配置の工夫がなされてい る。そのため，ほぼ薄型化には限界が生じていることがうかがえる。 また, 重量低減については, 製造・施工上の要求が増加し, 開発研 究が進行中である。

（7）温水式パネルユニット・㦿材一体ユニット・蓄熱式電気床暖岸 の開発は, 床暖房開発の中心課題であり, 開発価値が高かったと考 えられる。これらの技術の特許は, 建築構法にも大いに関連があっ て, パネル, 床部材, 蓄熱部材, 熱部材, 製造・施工要求, 熱的要 求が主な要因となっていたことが考えられる。

\section{謝辞}

本研究の情報・資料提供にご協力いただいた建築団体, 特に直接 対応していただいた各位に深謝の意を表します。

注

1）本研究で述べている特許とは，工業所有権制度を示す。工業所有権制 度には，「特許法」，「実用新案法」，「意匠法」及び「商標法」という法 律に基づいて与元られる特許・実用新案・意匠・墑標があり, 本研究 では, この特許と実用新案を対象としている。そこから得られる情報 を特許情報とした。

2）「1993年・建設名篮」から，情報収集するための対象建築㳡体の抽出 を行った。抽出した団体種類とその数, 及び回答数, 有効回答数, 資料 利用数は以下の通りである。

\begin{tabular}{|c|c|c|c|c|}
\hline 抽出建筑関係団体種類 & 回答数 & 有効回答数 & 資料利用数 \\
\hline 建材系団体 & 16 & 8 & 2 & 0 \\
\hline 設備系団体 & 14 & 7 & 7 & 2 \\
\hline 室内事業系団体 & 6 & 5 & 3 & 1 \\
\hline 床工事関係団体 & 3 & 2 & 0 & 0 \\
\hline その他 & 2 & 2 & 1 & 0 \\
\hline
\end{tabular}

3）特許情報収集の予備調查として, 近华の公開特許 ${ }^{4}$ ) により床暧房に関 する特部情報の一時的な检索を行い，抽出を行った。この結果，「発明 の名称」により床暖房関係の特許・実用新案の IPC 国際分類 ${ }^{7)}$ の検索 䉪四を限定することが可能となった。

この検索では，「床暖房，ヒ一ティング，輻射，面状発熱体」等の床 暖房に関する一般的なキーワードから関連特許情報を抽出し，その抽 出された特許情報の IPC 国際分類の分布を調查したところ, 以下のよ 
うな分類項目があげられた。

Eセクション：固定構造物

Fセクション: 機械工学, 照明, 加熱, 武器, 爆破

Hセクション: 電気

上記の分類項目のセクションにおいて，床暖房に対する範囲は限定 され，検索された内容は，IPC 国際特許分類の内容と合致することが分 かった。ここで, Eセクション: 固定構造物の建築構法との関連性を 考慮した研究を行うことを目的として，特許情報の調査や分析を行う。 従って, 特許情報の収集は; Eセクション: 固定構造物を主体とした。

4） Eセクション：固定構造物は, 国際特許分類 ${ }^{8)}$ 中の一つに属している。 分類は，以下のように1〜9からなる。

1. A セクション 生活必需品

2. B セクション 処理操作; 運輸

3. C セクション 化学 ; 治金

4. Dセクション 䋐維; 紙

5. Eセクション 固定構造物

6. Fセクション 機械工学; 照明; 加熱; 武器 ; 爆破

7. G セクション 物理学

8. H セクション 電気

9. 指針书よび要約

9.の「指針」は, 配列, 記号の使用法, 分類の原則, 規則, 付与等に ついて説明したものであり,「要約」は各セクションのメイングループ までのリストをあげたものである。

また，Eセクション：固定構造物の内容や種類 ${ }^{8)}$ は次の通りである。

E01 道路，鉄道または橋りょうの建設

E02 水工; 基礎；土砂の移送

E03 上水; 下水

E04 建築物

E05 錠；鍵；空または戸の付属品；金属

E06 戸，空，シャッタまたはローラブラインド；はしご

E21 地中削孔; 採鉣

本研究の資料では，E04 内の特許が対象の殆どである。

5) PATOLIS オンラインサービス（特許情報コンピューター検索サービス） による収集は，(社) 発明協会において，以下のような条件での特許情 報の本検索を行った。

·特許書誌检索範囲（年次）

昭和 46 年頃〜平成 9 年 9 月 26 日発行まで

·実用新案書誌検索笔囲（年次）

昭和 55 年頃 平成 9 年 9 月 26 日発行まで

・特許情報を検索する際のフリーキーワード ${ }^{9)}$ 及び IPC 国際特許分 類検索範囲

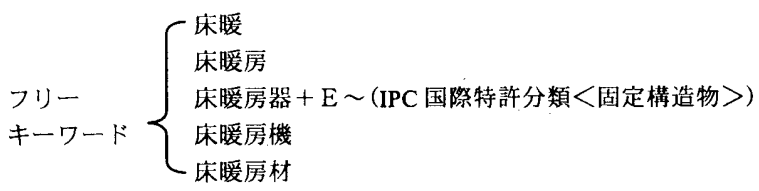

6) 本論文では, 図-8，9，11〜14 を特許資料による調査の, 主要分 類項目の年代分布として採用した。また，図一 $6 ， 7$ は特許資料によ る分類結果の分布である。

\section{参考文献}

1) 日本住宅設備システム協会編集，発行：「住宅設備機器関係データブッ ク」NO.4, 1982.10

日本住宅設備システム協会編集, 発行 :「住宅設備機器関係データブック」 NO.10, 1988.10

日本住宅設備システム協会編集，発行：「住宅設備機器関係データブック」 NO.16, 1994.10

日本住宅設備ジステム協会編集, 発行:「住宅設備情報ガイドj, 1979〜1994 建設物伍調查会編集，発行：「建築統計年報/H8 年度版」, 1996.8

2) 日本暖房機器工業会編集, 発行 :「暖房機器年鑑·暖房機器要目表付」, 1977 1995

3 ) 建築学大系編集委員会編集:「建築学大系 23 -建築設備計画」, 彰国社, 1976.10.10 新建築学大系編集委員会編集，井上宇一，篗原隆政，佐藤光男，中原信 生，西村博著：「新建築学大系 27 ·設備計画」, 彰国社, 1982.3.20 日本建築学会編集：「近代日本建築学発達史，8編噮境工学，7章暖房設 備」, 丸善, 19992.1.20

篠原隆政著 :「給排水衛生・暖房設備の変㟟」，水曜会, 1990.6.29 柳町政之助著：「その後の床暖房」，「衛工誌・10 巻 2 号」, 1936.2 井上宇一著：「冷凍空調史」，日本冷凍空調設備工業連合会，1993.4.1 特集·温水式床暖房，「建築手帪」No.201，金竜堂，1976.10.10 二渡勇美著：特許情報よりみた建材・建築技術，「建築手帳」No.203，金 竜堂, 1976.12 .10

特集·電気床暖房の現況と将来，「建築手帳」No.211，金竜堂，1977.9.10 二渡勇美著：特許情報よりみた建材・建築技術，「建築手艮」No.222，金 竜堂, 1978.9 .10

二渡勇美著：特許情報よりみた建材・建築技術，「建築手帳」No.232，金 童堂, 1979.8 .10

特集・温水床暖房システム(1), 「建築手帳」No.233, 金竜堂, 1979.12 .10 特集・電気床暖房システム(3),「建築手帳」No.242, 金竜堂, 1980.8 .10 二渡勇美著 : 特颜情報よりみた建材・建築技術, 特集・床暖房システム(2), 「建築手帪」No.251, 金竜堂, 1981.7.10

特集・電気式・温水式床暖房，「建築手脤」No.265, 金竜堂, 1982.9.10

4) 日本特許情報機構編集，発行：「公開特許·分類索引」, 1978,1979,1995.8.1

5 ) 電気床暖房工業会編集, 発行 : 「蓄熱式電気床暖房ハンドブック」 1992 年版, 1992.2

電気床暖房工業会編集, 発行:「電気床暖房製品便覧」平成 5 年版, 1993.10 日本床暖房工: 業会編集, 発行 : 「温水床暖房-快適・健康的な省エネシス テムー」, 1986.10.20

日本床暖房工業会編集, 発行 : 「温水床暖房システム 設計・施工ハンド ブック」, 1993.2.1

6 ）最新建築内外装ハンドブック編集委員会編集：「最新建築内外装ハンド ブック」, 建設産業調査会, 1981.1.20

7 ) 特許庁編集，(社)発明協会発行：「IPC 特許・寒用新案国際特許分類表（第 6 版) 」, 1995.8 .25

8) 日本特許打編集，発行：「特許打公報 国際特許分類表(第 6 版)第 5 巻(E セクション)」, 1994.10.18

9 ）日本特許情報機構編集，発行：「PATOLIS フリーキーワード一覧表」，1995

10）大島隆一, 小西敏正, 桝田佳寛, 金子和人：住宅暖房設備における部品・ 構法の変遷史, 日本建築学会大会学術講演梗概集(近畿), pp.593 594, 1996.9

11）大島隆一，小西敏正，桝田佳寛，田島宏一：床暖房設備における部品・

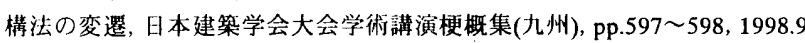

